\title{
Morphometric Analysis of Mersa Matrouh Wadi Basins, Egypt Using ASTER (DEM) Data and Spatial Information Techniques
}

\author{
By
}

\section{Hamdeno Abdel Kader Al-Awady}

Geography Department, Alexandria University, Alexandria, Egypt

\begin{abstract}
:
Projected Digital Elevation Model (ASTER-DEM-30m), Geographical Information Systems (GIS) and global Positioning System (GPS) were prepared and used to evaluate the morphometric aspects of seven drainage basins in Mersa Matrouh area namely from east to west are: Kharruba, el-Raml, Madwar, Magid, el-Washka, Senab and Umm-Ashtan watersheds. Results of morphometric parameters such as linear (one dimension), areal (two dimensions) and relief (three dimensions) aspects of the wadi basins revealed that the drainage basins occupy an area of about 388 sq.km and they were found to be strongly elongated with mean elongation ratio of 0.42 and mean circularity ratio of 0.21 . The basin drainage density was considered to be low as well as stream frequency and bifurcation ratio indicating the surface runoff has low potential and it is not quickly discharged. On the other hand, the studied drainage basins are characterized by low to moderate relief. Accordingly, the basin's area has a good groundwater prospect can be used to agricultural activity. The present study may be useful in water resources management for sustainable development.
\end{abstract}

Keywords: Morphometric Analysis, Geographical Information systems, Mersa Matrouh Drainage Basins, Parameters, Hydrologic, Processes.

\section{INTRODUCTION}

Morphometry is the measurement and mathematical analysis of the configuration of the earth's surface, shape and dimension of its landforms (Clarke, 1966; Agarwal, 1998; Obi Reddy et al., 2002). A major emphasis in geomorphology over the past several decades has been on the development of quantitative physiographic methods to describe the evolution and behavior of surface drainage networks 
(Horton, 1945; Leopold \& Maddock, 1953; Abrahams, 1984). Most previous morphometric analyses were based on arbitrary areas or individual channel segments. Using watershed as a basic unit in morphometric analysis is the most logical choice. A watershed or drainage basin is the surface area drained by a part or the totality of one or several given water courses and can be taken as a basic erosional landscape element where land and water resources interact in a perceptible manner. In fact, the modern approach of quantitative analysis of drainage basin morphology was given inputs by Horton (1945) the first pioneer in this field. Horton's laws were subsequently modified and developed by several geomorphologists, most notably by Strahler (1952, 1957, 1958, and 1964), Schumm (1956), Morisawa (1957, 1958), Scheidegger (1965), Shreve (1967), Gregory (1966, 1968), Gregory and Walling (1973). Subsequently a number of books by Bloom (2002), Keller and Pinter (1996) have further propagate the Morphometric analysis.

The morphometric analysis is done successfully through measurement of linear, aerial, and relief of the basin (Nautiyal 1994; Nag and Chakraborty, 2003; Magesh et al. 2012b). A widely acknowledged principle of morphometry is that drainage basin morphology reflects various geological and geomorphological processes over time, as indicated by various morphometric studies (Horton 1945; Strahler 1952, 1964; Muller 1968; Shreve 1966; Evans 1972, 1984; Chorley et al. 1984; Merritts and Vincent 1989; Ohmori 1993; Cox 1994; Oguchi 1997; Burrough and McDonnell 1998; Hurtrez et al. 1999). It is well established that the influence of drainage morphometry is very significant in understanding the landform processes, soil physical properties and erosional characteristics. 
The Digital Elevation Model (DEM) of the study area was generated to deduce the morphometric parameters such as drainage basin area, drainage density, drainage order, relief and other network characteristics. The geographic and geomorphic characteristics of a drainage basin are important for hydrological investigations involving the assessment of surface water and groundwater potential.

The present study aims to study the morphometric characteristics of Mersa Matrouh drainage basins using GIS techniques and also to provide basic information and maps that can be used for assessing groundwater potential, basin management and environmental assessment in the area of drainage basins.

\section{STUDY AREA}

The area of investigation is located in the Egyptian North West Coast, between latitudes $31^{\circ} 07^{\prime} 54^{\prime \prime}-31^{\circ} 23^{\prime} 04^{\prime \prime} \mathrm{N}$ and longitudes $26^{\circ} 58^{`} 9^{\prime \prime}-27^{\circ} 13^{`} 17^{\prime} \mathrm{E}$ (Fig.1), covering an area of $388.54 \mathrm{~km}^{2}$ in Matrouh Governorate. Temperature and rainfall data of twenty-nine years (1976-2005) were obtained from Mersa Matrouh Station. These data indicated that the climate of the study area is arid to semi-arid in nature, as the mean of maximum temperature ranges from $17.8{ }^{\circ} \mathrm{C}$ (January) to $29.8^{\circ} \mathrm{C}$ (August), with annual average of $24.1^{\circ} \mathrm{C}$. While, the mean of minimum temperature ranges from $9.2{ }^{\circ} \mathrm{C}$ (January) to $21.9{ }^{\circ} \mathrm{C}$ (August) with annual average of $15.2{ }^{\circ} \mathrm{C}$. On the other hand, the average annual rainfall is about $173.6 \mathrm{~mm}$, most of quantity (133.6 $\mathrm{mm}$ ) is precipitated from November to March. During the period of records, the maximum 24 hours' precipitation is $79.0 \mathrm{~mm}$. It has been repeated in many days during winter season under the effect of atmospheric depressions.

As Geologic Map of Egypt (NH 35 NE, scale 1:500 000) indicates the rocks forming the surface of the study area are of 
sedimentary origin and range in age from the Middle Miocene to the Holocene. The Middle Miocene and Pliocene rocks are fossiliferous shallow marine platform limestone with few marly intercalations (Marmarica Formation) and white sallow marine limestone with interbedded marl (El-Hagif formation). These rocks are widely distributed in the upper and middle portions of the investigated drainage basins (Fig. 2). To the north, the Quaternary deposits are developed in coastal plain (Sahl Rabah) and formed of calcarenite bars of Pleistocene as well as wadi alluvium, salt marshes, dune sands and recent coastal deposits.

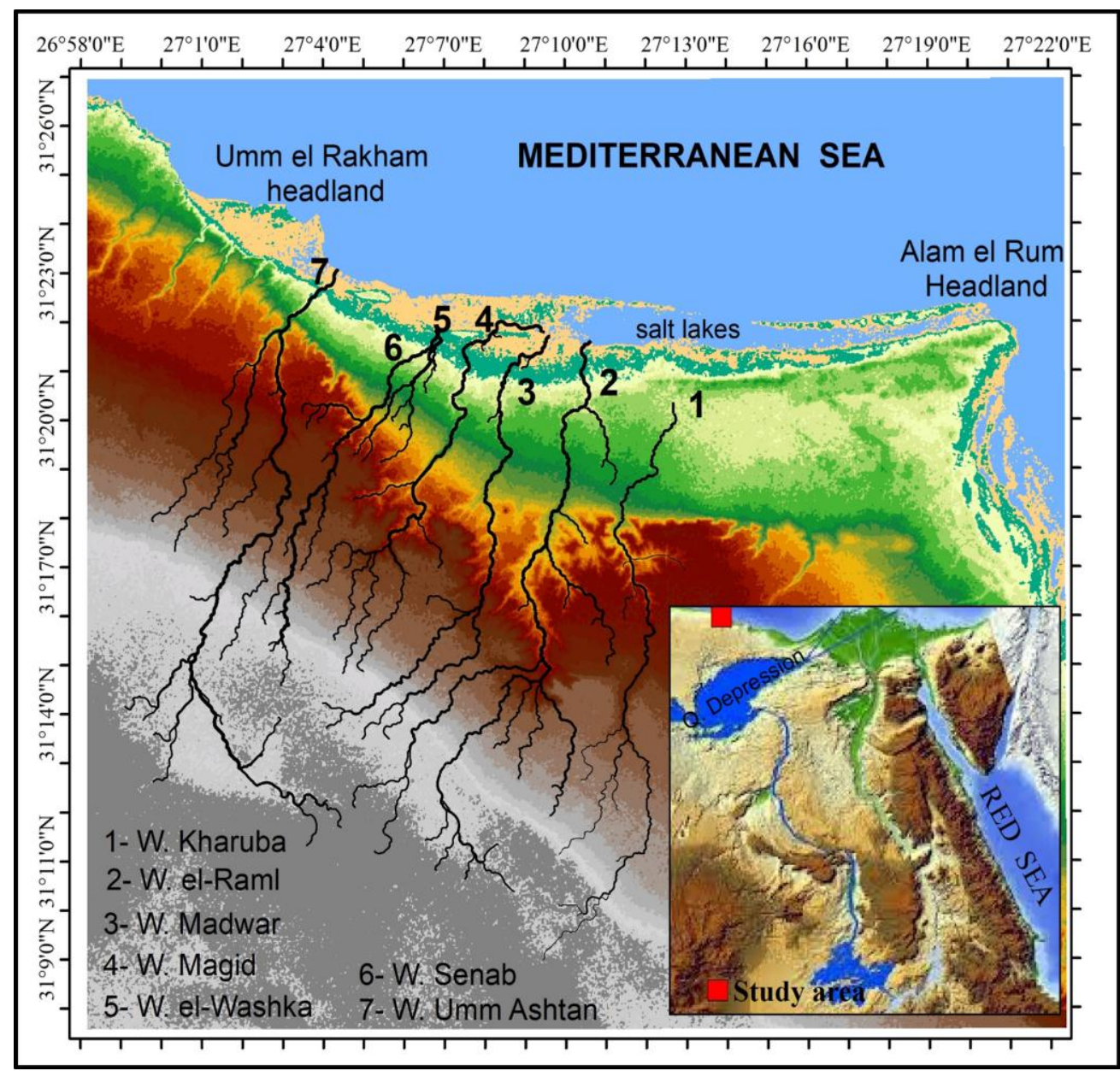

- Figure 1: Location Map of Mersa Matrouh's Wadies (1-W.Kharuba 2-W.el-Raml 3-W.Madwar 4-W.Magid 5-W.el-Washka 6-W.Senab 7W.Umm Ashtan) 
Physiographically, the study area is characterized by a low relief and simple topography. Its altitude rarely exceeds two hundred meters above sea level. Two main physiographic units are recognized, the table-land area (Marmarica plateau) to the south and the coastal plain (Sahl Rabah) to the north. The Table-land area is constituted by Miocene limestone capped by pink Pliocene silty limestone. It is dissected by numerous small deep consequent drainage lines running in a north-east direction towards the sea. The northern scarp of this plateau faces the sea and is more or less parallel to the present coast line. It is probably an erosional feature, attesting for an important period of transgression of the Pleistocene sea over the actual coastal plain.

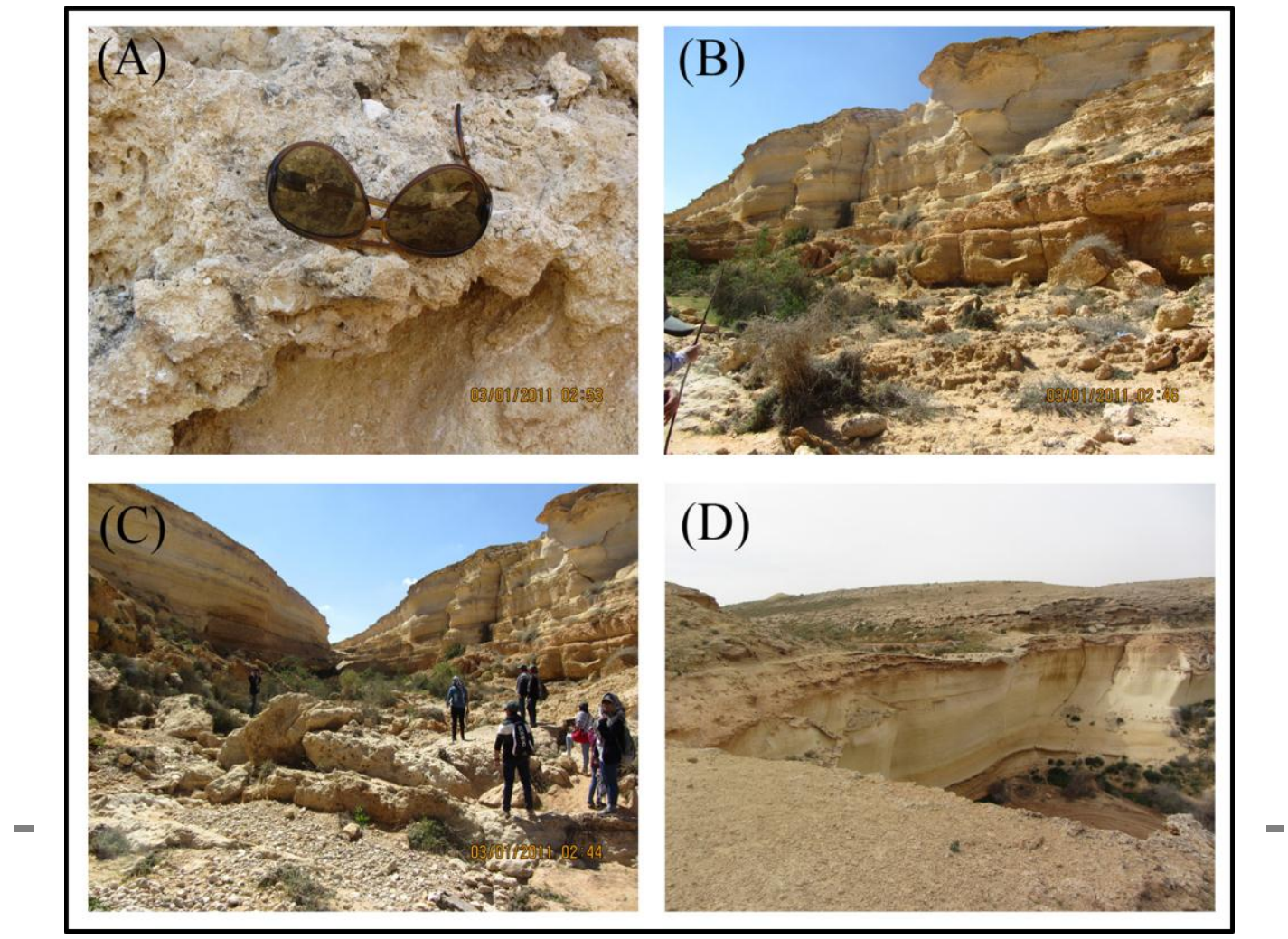

Figure 2: Deep wadi Courses in Limestone Rocks of the Study Area 
On the other hand, the coastal plain is constituted by different Quaternary deposits. Its floor is covered by clayey and silty sediments, suitable for agriculture (Cherif et al., 1975). The coastal plain is disturbed by two conspicuous coastal ridges, consisting of Oolitic marine limestone, overlain either by loose snow-white calcareous Oolitic sands or by recent sand dunes. To the south, the coastal plain is dotted by several scattered monticules, consisting of sandy limestones and marls, arranged in a line more or less parallel to the shore.

Morphologically, drainage lines in Mersa Matrouh area are either dendritic or parallel drainage pattern. Dendritic drainage pattern is especially associated with argillaceous limestone and calcareous shales. While the parallel drainage pattern is very common where calcareous rocks predominate. On the other hand, they are either straight or show different degrees of meandering. Valley sides exhibit various slope angles, mostly covered with rock fragments of variable sizes. They build up vertical cliffs forming excellent exposures. It is beyond doubt that the present day $173.6 \mathrm{~mm} /$ annum rainfall cannot cut such deep valleys which must have been sculptured during the rainy pluvial phases of the Pleistocene (Hassanein and El Senussi, 1984).

\section{MATERIALS AND METHODS}

The ASTER DEM- 30m spatial resolution of Mersa Matrouh Area re-projected and transformed to the regional projection (WGS-1984, UTM Zone $35 \mathrm{~N}$ ) as output coordinate system. The watersheds of interest are automatically extracted individually from the ASTER 
DEM data using various Geo-Processing Techniques of Arc GIS10.3. The DEM and the pour point are the two input parameters required for the extraction purpose. A pour point is a user-supplied point to the pixels of highest flow accumulation (Magesh et al. 2013). Drainage networks of the investigated basins are also extracted from DEM data using available Geo-processing and Hydrologic options of Arc GIS-10.3. such as fill, flow direction, flow accumulation, raster calculation, depending on (flow accumulation $>75$ ) \& (watershed $<$ 0 ), then stream link, stream to feature (drainage network), stream order and zonal statistics as table. The output of this method is a basis for creating a stream/ drainage network grid with stream order based on Strahler (1964). The output of the drainage network is smoothened using a smooth line tool.

Three major morphometric aspects are grouped and utilized namely: basin geometry and form, Drainage network, and relief basin. Some aspects of which such as basin area, basin length, mean basin width, basin perimeter, stream order, stream number, stream length, and mean stream length were extracted from Digital Elevation Model (DEM) and calculated using spatial analyst tools of ArcGIS-10.3 software. Other aspects such as elongation ratio, circularity ratio, form factor, bifurcation ratio, stream frequency, drainage density, basin relief, relief ratio, relative relief, and ruggedness ratio were computed and evaluated with established mathematical equations (Table.1). Stream ordering has been generated using Strahler (1964) system. The morphometric linear aspects were studied using the methods of Horton (1945), Strahler (1964), Chorley (1967), the areal aspects using those of Schumm (1956), Strahler (1956, 1968), Miller (1953), and Horton (1932), and the relief aspects employing the techniques of Horton (1945), Broscoe (1959), Melton (1957), Schumm (1954), Strahler (1952), and Pareta (2004). 
Table 1: Morphometric Analysis of Mersa Matrouh Drainage Basins - Comparative Characteristics

\begin{tabular}{|c|c|c|c|c|}
\hline Sr.No. and Parameter & Formulae & Reference & \multicolumn{2}{|c|}{ Results } \\
\hline \multicolumn{3}{|c|}{ A. Basin Geometry and form } & Range & Mean \\
\hline 1. Basin Area (sq.km) & GIS Software Analysis & Schumm (1956) & $8.61-107.48$ & 55.50 \\
\hline 2. Basin Length (km) & GIS Software Analysis & Schumm (1956) & $6.67-26.35$ & 19.17 \\
\hline 3. M. Basin Width (km) & $W b=A / L b$ & Horton (1932) & $1.19-4.61$ & 2.62 \\
\hline 4. Basin Perimeter $(\mathrm{km})$ & GIS Software Analysis & Schumm (1956) & $17.62-75.70$ & 56.25 \\
\hline 5. Elongation Ratio $(\mathrm{Re})$ & $R e=2^{\sqrt{A / \pi}} / L b$ & Schumm (1956) & $0.52-0.31$ & 0.42 \\
\hline 6. Circularity Ratio (Rc) & $R c=4 \pi A / P^{2}$ & Miller (1953) & $0.12-0.35$ & 0.21 \\
\hline 7. Form Factor $\left(\mathrm{R}_{\mathrm{f}}\right)$ & $R f=A / L b^{2}$ & Horton (1932) & $0.07-0.21$ & 0.14 \\
\hline \multicolumn{5}{|l|}{ B. Drainage Network } \\
\hline 8. Stream Order $(\mathrm{Su})$ & Hierarchical Rank & Strahler (1952) & $4-5$ & - \\
\hline 9. Stream Number $(\mathrm{Nu})$ & $N_{u}=N_{1}+N_{2}+\cdot \cdot N_{n}$ & Horton (1945) & $41-647$ & 314 \\
\hline 10. Stream Length $(\mathrm{Lu})$ & $L_{u}=L_{1}+L_{2}+\cdot \cdot L_{n}$ & Strahler (1964) & $25.69-353.7$ & 182.6 \\
\hline 11. M. St. Length (Lum) & see Table 2 & Horton (1945) & $0.40-16.55$ & - \\
\hline $\begin{array}{lll}\text { 12. } & \text { Bifurcation } & \text { Ratio } \\
(\mathrm{Rb}) & \end{array}$ & $R b=N_{u} / N_{u}+1$ & Strahler (1964) & $3.21-5.57$ & 4.29 \\
\hline $\begin{array}{l}\text { 13. Stream Frequency } \\
\text { (Fs) }\end{array}$ & $F s=N u / A$ & Horton (1932) & $4.72-6.28$ & 5.29 \\
\hline $\begin{array}{l}\text { 14. Drainage Density } \\
\text { (Dd) }\end{array}$ & $D d=L u / A$ & Horton (1932) & $2.98-3.33$ & 3.24 \\
\hline \multicolumn{5}{|l|}{ C. Relief Basin } \\
\hline 15. Basin Relief $(\mathrm{H})$ & $H=Z-z$ & Strahler (1952) & $119-185$ & 169 \\
\hline 16. Relief Ratio $\left(R_{h 1}\right)$ & $R h l=H / L b$ & $\begin{array}{l}\text { Schumm } \\
(1956)\end{array}$ & $6.72-17.84$ & 9.90 \\
\hline 17. Relative Relief $(R h p)$ & $R h p=H * 100 / P$ & Melton (1957) & $0.23-0.68$ & 0.35 \\
\hline $\begin{array}{l}\text { 18. Ruggedness Number } \\
(R n)\end{array}$ & $\begin{array}{l}R n=D d *(H / \\
1000)\end{array}$ & $\begin{array}{l}\text { Patton \& Baker } \\
\text { (1976) }\end{array}$ & $0.35-0.61$ & 0.55 \\
\hline
\end{tabular}

\section{RESULTS AND DISCUSSION}


The morphometric analysis of Mersa Matrouh drainage basins was carried out using data of topographic maps (NH 35-6 sheets) on the scale 1:25,000, Landsat-ETM+ with $30 \mathrm{~m}$ spatial resolution, ASTER-DEM with $30 \mathrm{~m}$ spatial resolution and field data. results of different morphometric parameters are listed in Tables 2-5.

\subsection{Basin Geometry and Form}

The most significant geometric and formal aspects of drainage basins are: basin area (A), basin length (Lb), Mean basin width $(\mathrm{Mwb})$ and basin perimeter $(\mathrm{P})$. As well as elongation ratio $(\mathrm{Re})$, circularity ratio $(\mathrm{Rc})$ and form factor $\left(\mathrm{R}_{\mathrm{f}}\right)$. Some were extracted using spatial analyst tools of Arc GIS 10.3, and others were calculated depending on conventional methods and functions.

\subsubsection{Basin Area (A)}

Although basin area by itself is an important independent variable, it has also been employed to manifest a variety of other parameters, each of which has a particular significance in basin geomorphology, especially in regard to the collection of rainfall and concentration of runoff (Ritter et al., 1995). Basin area was computed using ArcGIS-10.3 software. The studied drainage basin areas range from 8.61 sq.km to 107.48 sq.km, with an average of 55.50 sq.km, the basin of Al-Washka wadi has the lowest basin area, while the basin of Umm Ashtan has the highest basin area. The total catchment area of basins is 388.54 sq.km. Schumm (1956) established an interesting relation between the total watershed areas and the total stream lengths, which are supported by the contributing areas.

\subsubsection{Basin Length $(\mathrm{Lb})$}

Basin length has defined in different ways, for example, Schumm (1956) defined the basin length as the longest dimension of the basin parallel to the principal drainage line. Gregory and Walling (1968) defined the basin length as the longest in the basin in which are end 
being the mouth. Gardiner (1975) defined the basin length as the length of the line from a basin mouth to a point on the perimeter equidistant from the basin mouth in either direction around the perimeter. According to the definition of Schumm (1956) the investigated drainage basin lengths range from $6.67 \mathrm{~km}$ to $26.35 \mathrm{~km}$, with an average of $19.17 \mathrm{~km}$. In general, the basin area and the basin length both are proportional and they show almost positive relationship. As the data of Table 2 indicates, the basin area is maximum when the basin length has a high value.

Table 2: Geometric and Formal Aspects of Mersa Matrouh Drainage Basins

\begin{tabular}{|l|c|c|c|c|c|c|c|}
\hline \multirow{2}{*}{ Basin } & \multicolumn{4}{|c|}{ Basin geometry } & \multicolumn{3}{c|}{ Basin's form } \\
\cline { 2 - 8 } & $\mathrm{A}\left(\mathrm{km}^{2}\right)$ & $\mathrm{Lp}(\mathrm{km})$ & Mwb $(\mathrm{km})$ & $\mathrm{P}(\mathrm{km})$ & $\mathrm{Re}$ & $\mathrm{Rc}$ & $\mathrm{Rf}$ \\
\hline Kharruba & 55.12 & 24.25 & 2.27 & 70.81 & 0.35 & 0.14 & 0.09 \\
\hline El-Raml & 102.85 & 22.14 & 4.61 & 73.10 & 0.52 & 0.24 & 0.21 \\
\hline Madwar & 44.79 & 19.63 & 2.28 & 57.64 & 0.38 & 0.17 & 0.12 \\
\hline Magid & 50.85 & 19.25 & 2.64 & 54.18 & 0.42 & 0.22 & 0.14 \\
\hline El-Washka & 8.61 & 6.67 & 1.29 & 17.62 & 0.50 & 0.35 & 0.19 \\
\hline Senab & 18.84 & 15.89 & 1.19 & 44.70 & 0.31 & 0.12 & 0.07 \\
\hline Umm Ashtan & 107.48 & 26.35 & 4.08 & 75.70 & 0.44 & 0.24 & 0.15 \\
\hline average & 55.50 & 19.17 & 2.62 & 56.25 & 0.42 & 0.21 & 0.14 \\
\hline
\end{tabular}

Source: Data of SRTM-DEM- 30m resolution

\subsubsection{Mean Basin Width (Mwb)}

The width of the basin affects the precipitation level and flooding flow (Chorley,1986). The measured mean width (A/Lb) of the investigated drainage basins is ranged from $1.19 \mathrm{~km}$ to $4.61 \mathrm{~km}$, with an average of $2.62 \mathrm{~km}$ (Table 2). Although, these drainage basins are narrow in general, their central portions in comparison are wider, lead to increasing the volume of infiltration and evaporation, especially at the flat and gentle slope surfaces.

\subsubsection{Basin Perimeter $(P)$}


Basin perimeter which is the outer boundary of the watershed that enclosed its area, has measured using ArcGIS-10.3 software. Perimeters of the studied drainage basins range from $17.62 \mathrm{~km}$ to $75.70 \mathrm{~km}$, with general average of $56.25 \mathrm{~km}$ (Table 2). In general, the geometric characteristics of drainage basins are considered as significant affected aspects especially in the precipitation level, infiltration, and evaporation as well as surface runoff.

\subsubsection{Elongation Ratio (Re)}

Elongation ratio is a very significant index in the analysis of basin shape which helps to give an idea about the hydrological character of a drainage basin. Schumm (1956, p.612) defined the elongation ratio $(\mathrm{Re})$ as the ratio of a circle's diameter of the same area as the basin to the maximum basin length. Strahler stats that this ratio runs between $0.6-1.0$ over a wide variety of climatic types. The varying slopes of drainage basin can be classified with the help of the index of elongation ratio, i.e. circular (>0.9), oval (0.9-0.8), less elongated (0.8-0.7), elongated (0.7-0.5) and more elongated $(<0.5)$. the elongation ratio values of the investigated drainage basins range from 0.52 to 0.31 with an average of about 0.42 (Table 2). This is indicated that they have elongated to more elongated shapes. The elongated nature of the study basins has implication on both hydrologic and geomorphic processes. Mustafa and Yusuf (1999) have noted that the flow of water in elongated basins is distributed over a longer period than in circular ones.

\subsubsection{Circularity Ratio (Rc)}

Miller (1953, p.8) defined a dimensionless circularity ratio (Rc) as the ratio of basin area to the area of a circle having the same perimeter as the basin and it is pretentious by the lithological character of the watershed. He has described the basin of the circularity ratios range 0.4 to 0.5 which indicates strongly elongated 
and highly permeable homogenous geologic materials. Values of circularity ratio of the investigated drainage basins are ranged from 0.12 to 0.35 with an average of 0.21 (Table 2) indicating, according to the Miller's range, that the drainage basins of Mersa Matrouh are quite elongated in shape, low discharge of runoff and highly permeability of the subsoil condition.

\subsubsection{Form Factor $(\mathbf{R f})$}

Horton (1932) stated form factor as the ratio of the area of the basin and square of the basin length. Strahler (1964) noted that the shape of a drainage basin may conceivably affect stream discharge characteristics. Long narrow basins with high bifurcations would be expected to have attenuated flood - discharge periods, whereas rotund basins of low bifurcation ratio would be expected to have sharply peaked flood discharges. The form factor values of Mersa Matrouh drainage basins range from 0.07 to 0.21 with an average of 0.14 (Table 2). Thus, they are more elongated and have attenuated discharge periods.

\subsection{Drainage Network}

The most significant linear aspects of drainage network are: stream order, bifurcation ratio, stream frequency and drainage density. Some were extracted using spatial analyst tools of Arc GIS 10.3 , and others were calculated depending on conventional methods and functions.

\subsubsection{Stream Order $(\mathrm{Su})$}

There are available different systems of ordering stream networks (Horton, 1945; Strahler, 1952; Shreve, 1966; Scheidegger, 1970). In Strahler's system, a segment with no tributaries is designated as a first-order stream. Where two first-order segments join they form a second-order segment; two second-order segments join to form a 
third-order segment, and so on. Any segment may be joined by a channel of lower order without causing an increase in its order. Only where two segments of equal magnitude join are an increase in order required. The trunk stream is the stream segment of highest order (Ritter et al., 1995, p. 151). In the present study, ranking of streams has been carried out based on the method proposed by Strahler (1964) using GIS software. Details of stream order of several tributaries of Mersa Matrouh valleys are shown in the Table 3. Five from seven Wadies are designated as a fifth-order stream, these Wadies from east to west are: Kharruba, El Raml, Madwar, Majed, and Umm Ashtan. Only two Wadies (El Washka and Senab) are reached to fourth-order stream (Table 3 \& Fig. 3).

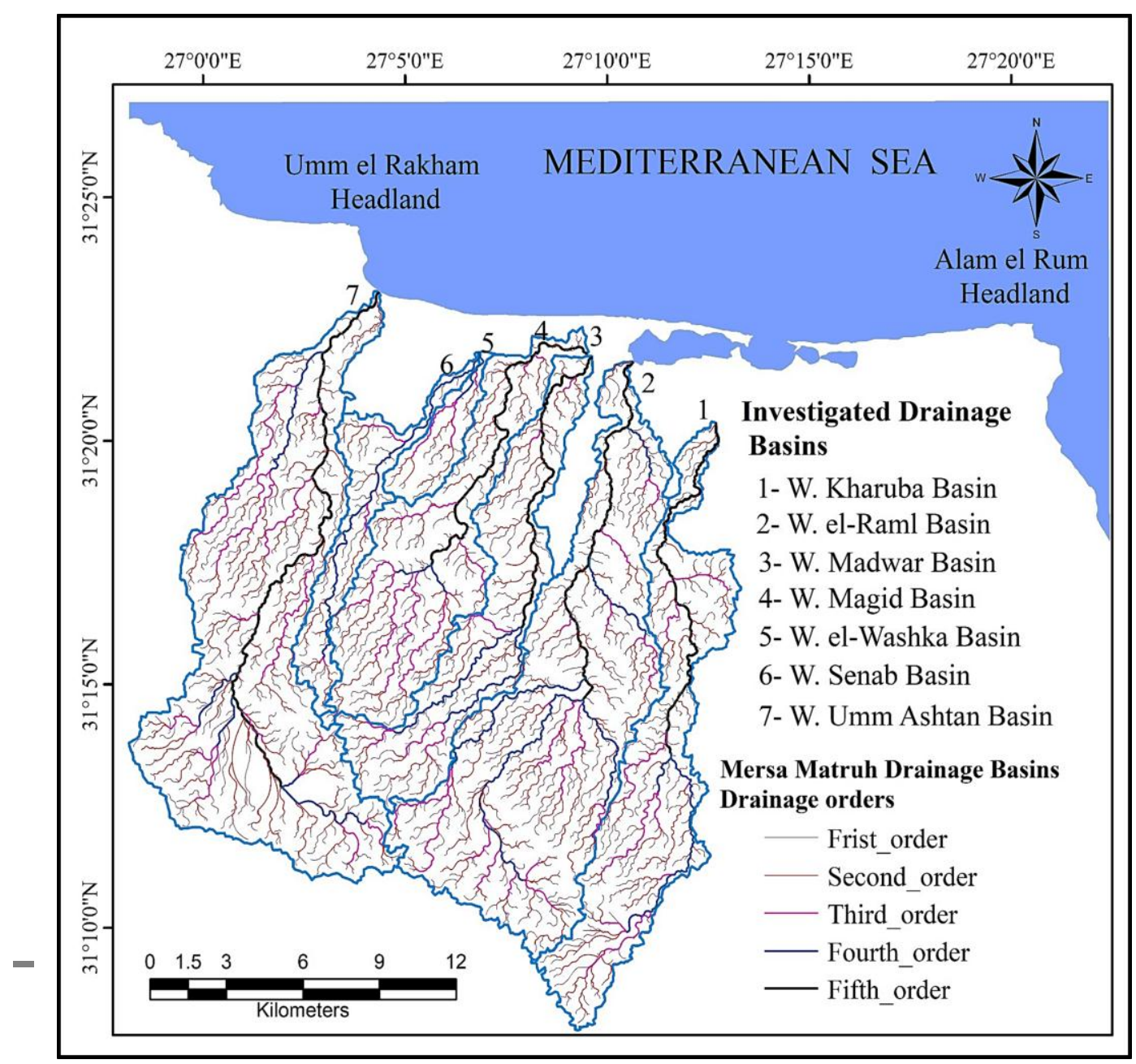

Figure 3: Drainage Networks and Drainage Orders of Mersa Matrouh's Watersheds 


\subsubsection{Stream Number $(\mathrm{Nu})$}

As per Horton's law (1945) of stream numbers, "the number of streams of different orders in a given drainage basin tends closely to approximate as inverse geometric series of which the first term is unity and the ratio is the bifurcation ratio". The maximum stream order frequency is observed in case of first-order streams and then for second order. In all 2185 drainage lines were identified of which 1547 $(70.80 \%)$ are first order, $542(24.81 \%)$ are second order, $73(3.34 \%)$ are third order, $18(0.82 \%)$ are fourth order and only $5(0.23 \%)$ comprise the fifth order (Table 3 ). it is noticed that there is a decrease in stream frequency as the stream order increases and vice versa (Fig. 4).

\subsubsection{Stream Length ( $\mathrm{Lu})$}

Stream length is one of the most important hydrological aspect of the area as it gives information about surface runoff characteristics. The stream length is a measure of the hydrological characteristics of the bedrock and the drainage extent. Wherever the bedrock and formation are permeable, only a small number of relatively longer streams are formed in a well-drained watershed, a large number of streams of smaller length are developed where the bedrocks and formations are less permeable. In general, the total length of river section is highest in first order stream and the length is inversely proportional to the stream order. Stream length data (Table 3) indicates that the total length of first order stream is $48.50 \%(619.82$ $\mathrm{km})$, second order stream is $17.56 \%(334.39 \mathrm{~km})$, third order stream is $11.55 \%(147.64 \mathrm{~km})$, fourth order stream is $7.30 \%(93.32 \mathrm{~km})$, and 
fifth order stream is $6.47 \%(82.74 \mathrm{~km})$. It is clearly identified that the cumulative stream length is higher in first-order streams and decreases as the stream order increases. The change of stream length $(\mathrm{Lu})$ may indicate flowing of streams from high altitude, lithological variation and moderately steep slopes (Singh and Singh, 1997).

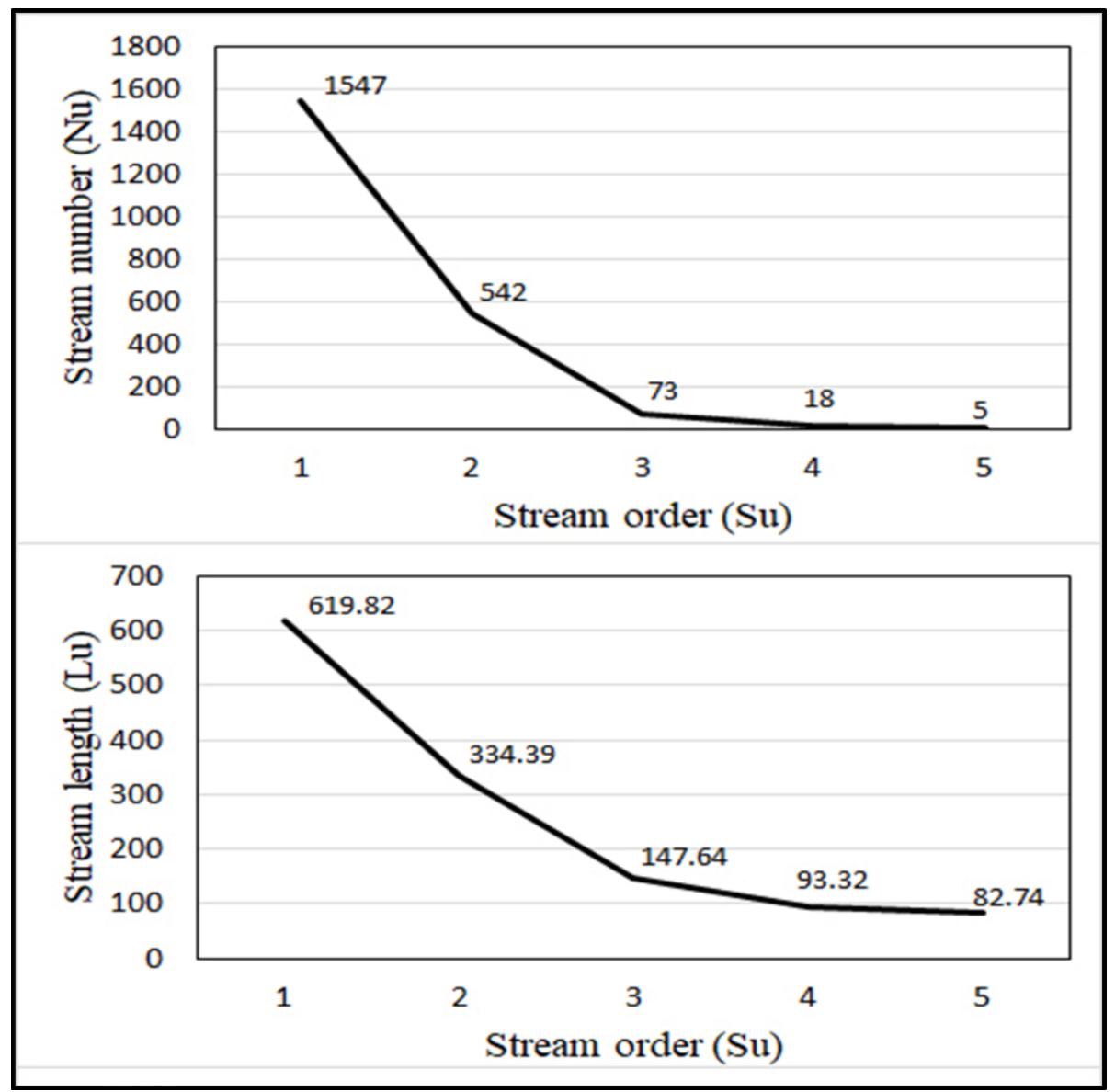

Figure 4: Stream Number and Stream Length Vs Stream Order

\subsubsection{Mean Stream Length (Lum)}

Mean Stream length (Lum) is a dimensional property revealing the characteristic size of components of a drainage network and its contributing watershed surfaces (Strahler, 1964). The mean stream 
length has been calculated by dividing the total length of stream of an order by total number of segments in the order. The mean stream length of first order stream is $0.40 \mathrm{~km}$, second order stream is 0.62 $\mathrm{km}$, third order stream is $2.02 \mathrm{~km}$, fourth order stream is $5.18 \mathrm{~km}$ and fifth order stream is $16.55 \mathrm{~km}$. It is clearly observed that the Lum values increase with increase of the stream order. The Lum values differ with respect to different basins, as it is directly proportional to the size and topography of the basin. Strahler (1964) indicated that the Lum is a characteristic property related to the size of drainage network and its associated surfaces. Mean stream length $(\mathrm{km})$ of the drainage networks under investigation based on stream order is shown in the Table 3.

Table 3: Stream Orders, Stream Numbers, and Other Network Parameters of Mersa Matrouh Watersheds

\begin{tabular}{|l|c|c|c|c|c|}
\hline \multicolumn{1}{|c|}{$(\mathrm{Su})$} & $(\mathrm{Nu})$ & $(\mathrm{Lu})$ & Lum & $\mathrm{A}\left(\mathrm{km}^{2}\right)$ & $\mathrm{Am}\left(\mathrm{km}^{2}\right)$ \\
\hline $1^{\text {st }}$ order & 1547 & 619.82 & 0.40 & 243.85 & 0.16 \\
\hline $2^{\text {nd }}$ order & 542 & 334.39 & 0.62 & 63.72 & 0.12 \\
\hline $3^{\text {rd }}$ order & 73 & 147.64 & 2.02 & 32.68 & 0.45 \\
\hline $4^{\text {th }}$ order & 18 & 93.32 & 5.18 & 22.53 & 1.25 \\
\hline $5^{\text {th }}$ order & 5 & 82.74 & 16.55 & 25.76 & 5.15 \\
\hline Total & 2185 & 1277.91 & - & 388.54 & - \\
\hline
\end{tabular}

Source: Data of SRTM-DEM- 30m resolution

\subsubsection{Bifurcation Ratio ( $R b)$}

The bifurcation ratio $(\mathrm{Rb})$ is defined as the ratio of the number of the stream segments of a given order $(\mathrm{Nu})$ to the number of streams in the next higher order ( $\mathrm{Nu}+1)$ (using Strahler ordering). Horton (1945) considered the bifurcation ratio as index of relief and dissertation. Strahler (1957) demonstrated that bifurcation shows a small range of variation for different regions or for different environment except where the powerful geological control dominates. The bifurcation ratio is dimensionless property and generally ranges from 3.0 to 5.0. 
The lower values of $\mathrm{Rb}$ are characteristics of the watersheds, which have affectless structural elements (Strahler 1964). The mean bifurcation ratio $(\mathrm{Mrb})$ values of the investigated drainage networks vary from 3.21 to 5.57 with general average of 4.29 (Table 4) indicating that the studied basin networks are less affect by structural features as well as they have low runoff potential.

\subsubsection{Stream Frequency (Fs)}

Stream frequency (Fs) is the total number of stream segments of all orders per unit area (Horton 1932). Stream frequency mainly depends on the lithology of the basin and reflects the texture of the drainage network. The present study indicated that the Fs values of drainage networks of Mersa Matrouh basins range from 4.73 to 5.93 $\mathrm{km} / \mathrm{sq} . \mathrm{km}$, with an average of $5.29 \mathrm{~km} / \mathrm{sq} . \mathrm{km}$ (Table 4), indicating the increase in stream population with respect to increase in drainage density. Channel frequency density serves as a tool in establishing the erosional processes operating over an area; to be more specific, the same in relation to the stream orders and their characteristics provides data which can throw light even on the sequences of relief developments and the degree of ruggedness in the area (Singh 1980).

Table 4: Mean Bifurcation Ratio, Stream Frequency, and Drainage Density of Mersa Matrouh Watersheds

\begin{tabular}{|l|c|c|c|c|c|}
\hline Basin & $\mathrm{Nu}$ & $\mathrm{Lu}$ & Mrb & Fs & Dd \\
\hline Kharruba & 296 & 183.32 & 4.16 & 5.37 & 3.33 \\
\hline el-Raml & 646 & 342.89 & 5.10 & 6.28 & 3.33 \\
\hline Madwar & 212 & 142.31 & 3.81 & 4.73 & 3.18 \\
\hline Magid & 263 & 167.81 & 4.02 & 5.17 & 3.30 \\
\hline el-Washka & 41 & 25.69 & 3.21 & 4.76 & 2.98 \\
\hline Senab & 90 & 62.06 & 4.14 & 4.78 & 3.29 \\
\hline Umm Ashtan & 647 & 353.74 & 5.57 & 5.93 & 3.29 \\
\hline average & 314 & 182.55 & 4.29 & 5.29 & 3.24 \\
\hline
\end{tabular}

Source: Data of SRTM-DEM- 30m resolution 


\subsubsection{Drainage Density (Dd)}

Drainage density (Dd) is a measure the total stream length in a given basin to the total area of the basin (Strahler 1964). It is significant aspect of drainage network analysis. Drainage density is related to various features of landscape dissection such as valley density, channel head source area, relief, climate, and vegetation (Moglen et al. 1998), soil and rock properties (Kelson and Wells 1989) and landscape evolution processes. As these factors vary from region to region, large variations in Dd can be expected. In general, resistant surface materials and those with high infiltration capacities exhibit widely spaced streams, consequently yielding low Dd. As resistance or surface permeability decreases, runoff is usually accentuated by the development of a greater number of more closely spaced channels, and thus Dd tends to be higher (Ritter et al., 1995). Drainage density of the investigated drainage basins was calculated, it has ranged from 2.98 to $3.33 \mathrm{~km} / \mathrm{km}^{2}$, with a general average of 3.24 $\mathrm{km} / \mathrm{km}^{2}$ (Table 4) which indicates that drainage basins have a highly resistant permeable subsurface material with intermediate drainage, low to moderate relief and low runoff potential.

\subsection{Relief Basin}

The most significant relief aspects of drainage basin are: the total relief $(H)$, relief ratio $\left(R_{h l}\right)$, relative relief $\left(R_{h p}\right)$ and ruggedness number $\left(R_{n}\right)$. Some were extracted using spatial analyst tools of Arc GIS 10.3, and others were calculated depending on conventional methods and functions (Table 5).

\subsubsection{Basin Relief $(\mathrm{H})$}

Basin relief is the maximum vertical distance between the highest and the lowest points of a basin. It is an important factor in understanding the denudation characteristics of the basin. Basin relief of the investigated basins range from $119 \mathrm{~m}$ to $185 \mathrm{~m}$, with an 
average of $169 \mathrm{~m}$ (Table 5 \& Fig. 5) indicating the textural dissection of the studied basins was considered to be low.

Table 5: Relief Aspects of Mersa Matrouh Watersheds

\begin{tabular}{|l|c|c|c|c|c|c|c|}
\hline Basin & $\mathrm{z}$ & $\mathrm{Z}$ & $\mathrm{H}$ & \multicolumn{2}{|c|}{$\mathrm{Rh} 1$} & $\mathrm{R}_{\mathrm{hp}}$ & $\mathrm{Rn}$ \\
\cline { 5 - 6 } & $(\mathrm{m})$ & $(\mathrm{m})$ & $(\mathrm{m})$ & $(\mathrm{m} / \mathrm{m})$ & $(\mathrm{m} / \mathrm{km})$ & $(\%)$ & \\
\hline Kharruba & 21 & 184 & 163 & 0.0067 & 6.72 & 0.23 & 0.54 \\
\hline el-Raml & 0 & 184 & 184 & 0.0083 & 8.31 & 0.25 & 0.61 \\
\hline Madwar & 0 & 182 & 182 & 0.0092 & 9.27 & 0.32 & 0.58 \\
\hline Magid & 0 & 179 & 179 & 0.0092 & 9.30 & 0.33 & 0.59 \\
\hline el-Washka & 6 & 125 & 119 & 0.0178 & 17.84 & 0.68 & 0.35 \\
\hline Senab & 7 & 179 & 172 & 0.0108 & 10.82 & 0.38 & 0.57 \\
\hline Umm Ashtan & 0 & 185 & 185 & 0.0070 & 7.02 & 0.24 & 0.61 \\
\hline average & - & 174 & 169 & 0.0099 & 9.90 & 0.35 & 0.55 \\
\hline
\end{tabular}

Source: Data of SRTM-DEM- 30m resolution

\subsubsection{Relief Ratio $\left(R_{h 1}\right)$}

The relief ratio is defined as the ratio between the total relief of a basin and the longest dimension of the basin parallel to the main drainage line (Schumm, 1956). The possibility of a close correlation between relief ratio and hydrologic characteristics of a basin suggested by Schumm (1956) who found that sediments loose per unit area is closely correlated with relief ratios. The study of Mersa Matrouh drainage basins reveals that the values of relief ratio are ranged from 0.0067 to $0.0178 \mathrm{~m} / \mathrm{m}$ or from 6.72 to $17.84 \mathrm{~m} / \mathrm{km}$, with general average of $0.0099 \mathrm{~m} / \mathrm{m}$ or $9.90 \mathrm{~m} / \mathrm{km}$ (Table 5 ). Low values of relief ratio are mainly attributed not only to the common flat and gentle slopes, but also to highly permeability of the subsoil condition. Therefore, wide area around valley sides and their alluvial fans could be basically used for agricultural activities, depending on winter rainfall and available underground water.

\subsubsection{Relative Relief $(R h p)$}


Relative relief is an important morphometric variable used for the assessment of morphological characteristics of any topography (Gayen et al. 2013). Relative relief of the studied drainage basins was calculated using Melton's formula. Values of relative relief range from 0.23 to 0.68 with an average of 0.35 (Table 5). The lower values indicate that the flat surfaces and gentle slopes are dominated especially in the lower sections of drainage basins.

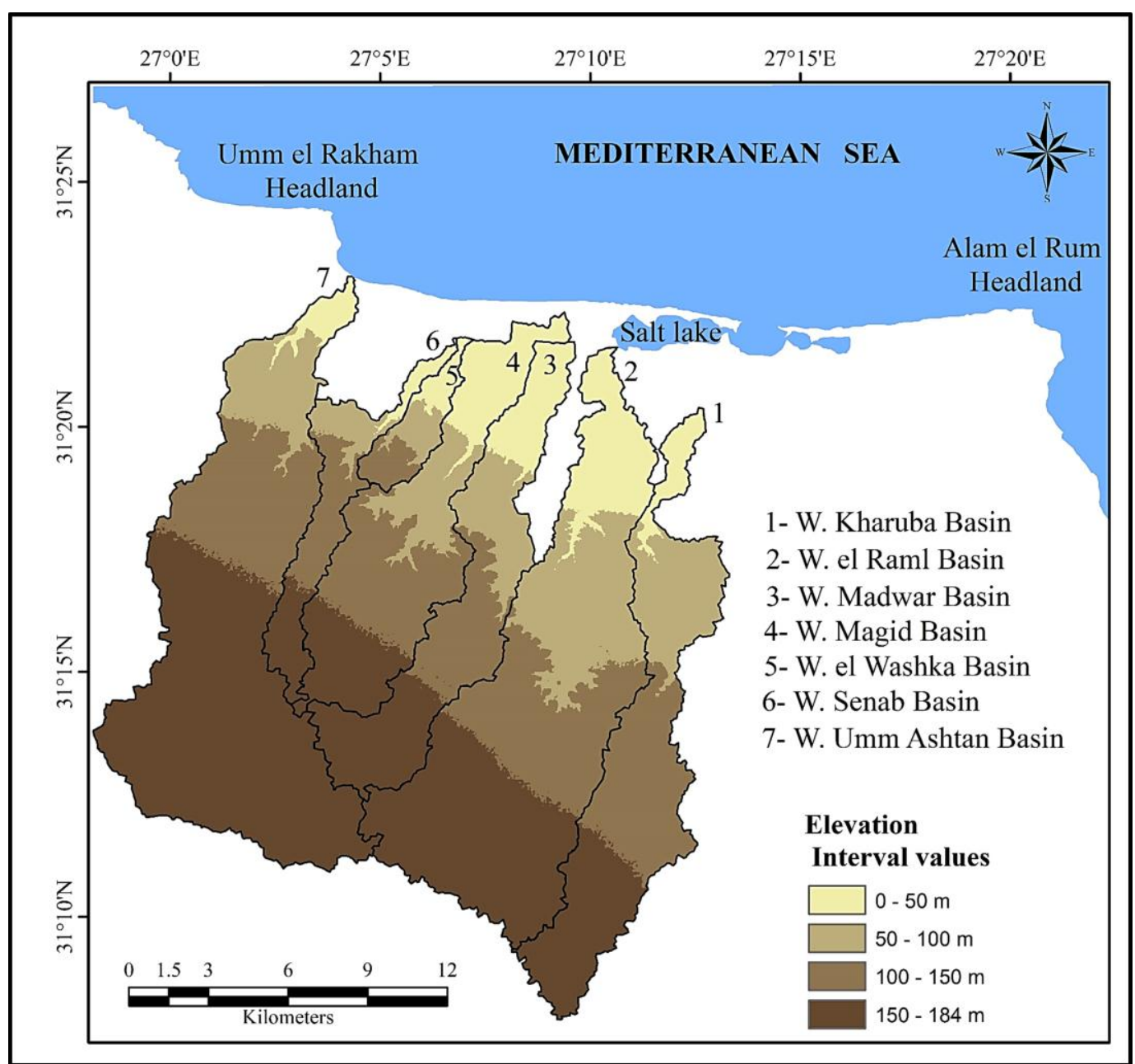

Figure 5: The Relief (Earth's Surface Elevation) of Mersa Matrouh Watersheds 


\subsubsection{Ruggedness Number $(R n)$}

Strahler (1968) describes ruggedness number $(\mathrm{Rn})$ as the product of maximum basin relief $(\mathrm{H})$ and drainage density $(\mathrm{Dd})$ and it usually combines slope steepness with its length. Extremely high values of ruggedness number occur when slopes of the basin are not only steeper but also long. The studied drainage basins have low values; they are ranged from 0.35 to 0.61 with an average of 0.55 (Table 5). Therefore, the textural dissection of the studied basins was considered to be low as drainage density and stream frequency. Consequently, these basins have low relief and they have decreased peak discharge and less prone to soil erosion.

\section{Conclusion}

The morphometric analysis was carried out for seven drainage basins in Mersa Matrouh area through measurement of basin geometry and form, Drainage network, and relief basin aspects. Geometric and formal analysis reveals that the studied basins are having low relief and elongated in shape, as well as they having low degree of runoff. On the other hand, drainage network analysis indicates on the basis of the drainage orders that the drainage basins of Mersa Matrouh area have been classified according to Strahler's method as $4^{\text {th }}$ and $5^{\text {th }}$ order basin. The variation in stream order, stream number and stream length might be due to change in basin slope and topography. The bifurcation ratio indicates that the drainage basin networks and their drainage patterns are not much affected by geological structures.

Drainage density and stream frequency are the most important criterion for the morphometric categorization of drainage basins which unquestionably control the runoff pattern, sediment yield and other hydrological parameters of the drainage basin. Values of 
drainage density and stream frequency reveal that the drainage basins of Mersa Matrouh area have low to moderate relief and low runoff potential, so that, the basin subsurface strata may differ from fairly permeable to permeable, where the field work indicates that the basin area has a good groundwater prospect can be used to agricultural activity.

It is important to be aware of the remotely sensed data (ASTERDEM) and GIS software techniques-based approach in evaluation of drainage morphometric parameters and their influence on landforms is more appropriate than the conventional methods. Hence, from the study it can be concluded that ASTER (DEM) data, coupled with GIS techniques, prove to be a competent tool in morphometric analysis of drainage basins. Finally, the study basin area is a promising area for the application of geomorphologic and water management studies.

\section{References}

Abrahams, A. D., (1984) Channel Networks: A Geomorphological Perspective, Water Resources. 20, pp 161-168.

Agarwal, C.S., (1998) Study of drainage pattern through aerial data in Naugarharea of Varanasi district U.P. Journal of the Indian Society of Remote Sensing 26: 169-175.

Broscoe, A.J., (1959) Quantitative Analysis of Longitudinal Stream Profiles of Small Watersheds", Project N. 389-042, Tech. Bep. 18, Geology Department, Columbian University, ONR, Geography Branch, New York.

Burrough, P.A., McDonnell, R.A., (1998) Principles of geographical information systems. Oxford University Press Inc., New York

Cherif, O.H., Bassiouni, M.A., and Ghanima, S.A., (1975) Stratigraphy, Paleoecology and Climates of the Neogene and Quaternary of the Mersa Matrouh Area, North Western Desert, Egypt. Annals of the Geol. Surv. Of Egypt, Vol. 5., pp. 137-147. 
Chorley, R.J., (1986) "The Application of Statistical Methods to Geomorphology. In: Essays in Geomorphology". London: G.H. Dury (ed).

Chorley, R.L., (1967) Models in Geomorphology. In R.J. Chorley and P. Haggett (eds.), Models in Geography, London, pp 59-96.

Clarke, C., (1966) Morphometry from Maps. Essays in Geomorphology, Elsevier Publ. Co., New York, Pp. 235-274, 1966.

Cox, R.T., (1994) Analysis of drainage-basin symmetry as a rapid technique to identify areas of possible quaternary tilt-block tectonics: an example from the Mississippi embayment. Geol. Soc. Am Bull 106:571-581

Evans, I.S., (1972) General geomorphometry, derivatives of altitude, and descriptive statistics. In: Chorley RJ (ed) Spatial analysis in geomorphology. Harper and Row, New York, pp 17-90

Evans, I.S., (1984) Correlation structures and factor analysis in the investigation of data dimensionality: statistical properties of the Wessex land surface, England. In: Proceedings of the Int. Symposium on Spatial Data Handling, Zurich., V. 1. Geographisches Institut, Universitat Zurich-Irchel. pp 98-116

Gardiner. V., (1975) Drainage Basin Morphometry. British Geomorphological Group, Technical Bulletin. 14; 48.

Gayen, S., Bhunia, G.S, and Shi, P.K., (2013) Morphometric analysis of Kangshabati-Darkeswar Interfluves area in West Bengal, India using ASTER DEM and GIS techniques. Geol Geosci 2(4):1-10

Gregory, K.J. \& Walling, D.E., (1968) The Variation of Drainage Density within a Catchment. International Association of Scientific Hydrology - Bulletin, 13, pp 6168.

Hassanein, A.M. and El Senussi, M.Y., (1984) Geomorphological Aspects of the Area Between Longitudes $26^{\circ} 3^{\prime}-2^{\circ} 30^{\circ} \mathrm{E}$ Along the Mediterranean Coastal Zone, Egypt. Bull. Fac. Sci. Zagazig Univ., 6., pp. 136-155.

Horton, R.E., (1932) Drainage Basin Characteristics. Transactions, American Geophysical Union, 13, pp 350-61. 
Horton, R.E., (1945) Erosional Development of Streams and their Drainage Basins. Bulletin of the Geological Society of America, 56, pp.275370.

http://srtm.csi.cgiar.org. "SRTM-30m Digital Elevation Data" CGIAR-CSI

Hurtrez, J.E, Sol, C., and Lucazeau, F., (1999) Effect of drainage area on hypsometry from an analysis of small-scale drainage basins in the Siwalik hills (central Nepal). Earth Surf Process Landform 24: pp.799-808

Kelson, K.I. and Wells, S.G., (1989) Geologic influences on fluvial hydrology and bedload transport in small mountainous watersheds, northern New Mexico, USA. Earth Surf Process 14: pp.671-690.

Krishnamurthy, J., Srinivas, G., Jayaram, V., and Chandrasekhar, M.G., (1996) Influence of rock type and structure in the development of drainage networks in typical hard rock terrain. ITC J 4(3):252-259

Leopold, L.B. \& Maddock, T., (1953) The hydraulic geometry of stream channels and some physiographic implications, USGS Professional paper, 252, pp.1-57.

Magesh, N.S., Jitheshlal, K.V., Chandrasekar, N., and Jini, K.V., (2012b) GIS based morphometric evaluation of Chimmini and Mupily watersheds, parts of Western Ghats, Thrissur District, Kerala. India Earth Sci Inform 5(2):111-121

Melton, M.A., (1957) An Analysis of the Relations among the Elements of Climate, Surface Properties and Geomorphology. Technical Report 11, Department of Geology, Columbia University, New York.

Miller, V.C., (1953) A Quantitative Geomorphic Study of Drainage Basin Characteristics in the Clinch Mountain Area, Virginia and Tennessee. Project NR 389-042, Technical Report: 3, Columbia University, Dept. of Geology, ONR, Geography Branch, New York.

Moglen, G.E., Eltahir, E.A., Bras, R.L., (1998) On the sensitivity of drainage density to climate change. Water Resour Res 34: pp.855862.

Muller, J.E., (1968) An introduction to the hydraulic and topographic sinuosity indexes. Ann Assoc Am Geogr 58:371-385 
Nag, S.K., Chakraborty, S., (2003) Influence of rock types and structures in the development of drainage network in hard rock area. J Indian Soc Remote Sens 31(1):25-35

Nautiyal, M.D., (1994) Morphometric analysis of a drainage basin, district Dehradun, Uttar Pradesh. J Indian Soc Remote Sens 22(4):251-261

Obi Reddy, GP., Maji, A.K., and Gajbhiye, KS., (2004) Drainage morphometry and its influence on landform characteristics in basaltic terrain, central Indian remote sensing and GIS approach, International Journal of Applied Earth Observations and Geoinformation, 6, pp 1-16.

Oguchi, T., (1997) Drainage density and relative relief in humid steep mountains with frequent slope failure. Earth's Surf Process Landforms 22:107-120

Ohmori, H., (1993) Changes in the hypsometric curve through mountain building resulting from concurrent tectonics and denudation. Geomorphology 8:263-277

Pareta, K., (2004) Hydro-Geomorphology of Sagar District (M.P.): A Study through Remote Sensing Technique", Proceeding in XIX M. P. Young Scientist Congress, Madhya Pradesh Council of Science \& Technology (MAPCOST), Bhopal.

Scheidegger, A.E., (1965) The Algebra of Stream Order Number. U.S. Geological Survey Professional Paper, 525B, B1, pp 87-89.

Scheidegger, A.E., (1970) Theoretical Geomorphology. 2nd edn. BerlinHeidelberg New York: Springer.

Schumm, S.A., (1954) The relation of Drainage Basin Relief to Sediment Loss", International Association of Scientific Hydrology, 36, pp 216-219.

Schumm, S.A., (1956) Evolution of Drainage Systems \& Slopes in Badlands at Perth Amboy, New Jersey", Bulletin of the Geological Society of America, 67, pp 597-646.

Shreve, R.L., (1966) Statistical Law of Stream Numbers. Journal of Geology, 74, pp 17-37. 
Singh, S. and Singh, M.C. (1997) Morphometric Analysis of Kanhar River Basin. National Geographical. J. of India. 43 (1) 31-43.

Singh, S., (1995) Quantitative analysis of watershed geomorphology using remote sensing techniques. Ann Arid Zone 34(4): 243-251

Strahler, A. N. (1957) Quantitative analysis of watershed geomorphology. Trans. Am. Geophysics. Un., 8, 913-920.

Strahler, A.N (1952) Hypsometric Analysis of Erosional Topography. Bulletin of the Geological Society of America, 63, pp 1117-42.

Strahler, A.N., (1956) Quantitative Slope Analysis. Bulletin of the Geological Society of America, 67, pp 571-596.

Strahler, A.N., (1964) Quantitative Geomorphology of Drainage Basin and Channel Network. Handbook of Applied Hydrology, pp 39-76. 